\title{
Seminal Analysis, Cryogenic Preservation, and Fertility in Matrinxã Fish, Brycon cephalus (Günther, 1869)
}

\author{
Alexandre Ninhaus-Silveira ${ }^{1 *}$, Fausto Foresti $^{2}$, Rosicleire Veríssimo-Silveira ${ }^{2}$ and José \\ Augusto Senhorini ${ }^{3}$ \\ ${ }^{1}$ Departamento de Biologia e Zootecnia; Universidade Estadual Paulista; Ilha Solteira; ninhaus@bio.feis.unesp.br; \\ São Paulo - SP - Brasil. ${ }^{2}$ Departamento de Morfologia; Universidade Estadual Paulista; Botucatu; São Paulo - SP - \\ Brasil. ${ }^{3}$ Centro de Pesquisa e Gestão de Recursos Pesqueiros Continentais; IBAMA; Pirassununga -SP - Brasil
}

\begin{abstract}
Aiming to improve fish reproduction techniques, the characterization and cryopreservation of semen of Brycon cephalus were performed. The seminal characteristics observed were: an almost transparent, milky semen with a mean volume of $4 \mathrm{~mL}$, and sperm concentration of $9.617 \pm 1.630 \times 10^{6}$ spermatozoa $/ \mathrm{mm}^{3}$. Spermatozoa $($ length $=$ $31.288 \pm 4.47 \mu \mathrm{m})$ were of the aquasperm type and displayed a small, round head (length $=1.727 \pm 0.18 \mu \mathrm{m} ;$ width $=$ $1.752 \pm 0.17 \mu \mathrm{m})$ without acrosomal vesicle, nucleus with highly condensed chromatin forming coarse clots and centriolar complex located in the nuclear fossa; a midpiece (length $=2.561 \pm 0.44 \mu \mathrm{m})$, narrowed rearward, with a cytoplasmic canal; and a flagellum (length $=29.521 \pm 4.37 \mu \mathrm{m})$. Fertilization tests with thawed semen demonstrated a significant effect $(\alpha=0.05)$ on the increase of thawed semen fertility with diluent type B in both $0.5 \mathrm{~mL}$ and $4.0 \mathrm{~mL}$ straws. No significant effect $(\alpha=0.05)$ on hatching rate was observed in both straw sizes used.
\end{abstract}

Key words: Semen characteristics, Cryopreservation, Brycon cephalus, Ultrastructure, Fish

\section{INTRODUCTION}

Cryopreservation of fish semen has contributed to the development and application of methods of reproductive control by favoring genetic manipulation, broodstock selection and reduction of male stock since it provides gametes for undetermined periods. In addition, these freezing methods may be used in hybridization programs, preservation of genetic material from endangered species and gene banking. The development of methods of semen preservation and the implementation of effective artificial reproduction protocols require a good knowledge of the reproductive biology and seminal characteristics (sperm concentration, semen color and volume, sperm morphology, etc.) of the targeted species.

In the neotropical species of interest for fish breeding, "ex situ" genetic preservation has been tested. Within this context, the efforts made by some investigators are noteworthy: the evaluation of fresh semen of the catfish Rhamdia hilarii (Valenciennes, 1840) and the cryopreservation semen in dry ice by Fogli da Silveira et al. (1981; 1985); the studies by Coser et al. about the conditions for the preservation of curimbatá (Prochilodus scrofa) semen (1984) and also the freezing and cryopreservation of piau (Leporinus silvestrii) semen (1987); the freezing of pacu (Piaractus mesopotamicus) semen by Carosfeld et

\footnotetext{
* Author for correspondence
} 
al. (1990); and the sperm evaluation, cryogenic preservation and semen fertility of $P$. mesopotamicus also carried out by Fogli da Silveira et al. (1990).

The semen characterization, as well as the cryopreservation techniques used in neotropical fish species are still incipient. For their development and qualitative control, specific information including data on the structure of spermatozoa is required. Among fish, different reproduction strategies and spermatozoa of varied morphology are described. In fishes of internal fertilization, spermatozoa usually display an elongated head and a more elaborate and structured midpiece. In species with external fertilization, spermatozoa commonly have a round, or oval head, and a small midpiece. Among Teleostei, spermatozoa exhibit no acrosome. Such condition is associated to the presence of a developed micropyle in the eggs of the species (Jamieson, 1981).

Brycon cephalus is a Brazilian migratory fish from the Amazon region, of annual maturation and total spawning. It is omnivorous and presents great adaptability to confined systems. Its flesh is of excellent quality and it reaches slaughter age at one year-old (Pereira Filho, 1994; Mendonça, 1994). It is remarkably valuable at the fish market as well as in the sport fishing trade. The purpose of this study was to determine the seminal characteristics of B. cephalus, including volume, sperm concentration, spermatozoa morphology and morphometry, and to establish an efficient and easy method for semen cryopreservation of this species.

\section{MATERIAL AND METHODS}

Adult specimens (three years-old) of B. cephalus from the broodstock of CEPTA - Centro de Pesquisa e Gestão de Recursos Pesqueiros Continentais - IBAMA, Pirassununga, São Paulo, Brazil were used as semen donors. They were kept in $1000-\mathrm{m}^{2}$ tanks and fed with commercial pellets (30\% protein content) until the beginning of reproduction. Spermiation was induced by one injection of $1 \mathrm{mg}$ of carp pituitary extract (CPE) per $\mathrm{kg}$ of body weight. After $6 \mathrm{~h}$, semen was collected by gentle abdominal pressing and stored in sterilized test tubes.

\section{Assessment of semen characteristic}

Semen was collected from twenty-five specimens of B. cephalus. The semen samples were evaluated for volume $(\mathrm{mL})$, determined by emptying the gonad until bleeding occurred; color; subjective motility rate $(0-5$ scale, with $\mathbf{0}=$ no motility, $\mathbf{1}=$ $10-20 \%, 2=20-40 \%, \mathbf{3}=40-60 \%, \mathbf{4}=60-80 \%$ and $\mathbf{5}=>80 \%$ of motile cells) (Fribourg, 1966) and, sperm concentration (spermatozoa $/ \mathrm{mm}^{3}=$ sperm $/ \mathrm{mm}^{3}$ ), obtained by using a Neubauer cell counting chamber. For the ultrastructural analysis of spermatozoa, an aliquot of each semen sample (fresh and thawed) was fixed in $4 \%$ paraformaldehyde and $2 \%$ glutaraldehyde in a $0.1 \mathrm{M}$ phosphate buffer $(\mathrm{pH} 7.3)$. For transmission electron microscopy (TEM), samples were postfixed in $1 \%$ osmium tetroxide for two hours, counterstained in a water solution of $0.5 \%$ uranyl acetate, dehydrated in acetone and embedded in Araldite resin. The ultra-thin sections were counterstained in uranyl acetate (Watson, 1958), washed in 50\% alcohol, once again counterstained in lead citrate (Reynolds, 1963), investigated and electromicrographed with a Phillips-CM 100 transmission electron microscope.

For scanning electron microscopy (SEM), the prefixed material was centrifuged (Fanem, Centimicro, 212) $(3 \mathrm{x} / 3 \mathrm{~min} / 1000 \mathrm{rpm})$ and transferred to a $13-\mathrm{mm}$-diameter slide covered by $1 \%$ poly-L-lysine, post-fixed in $0.5 \%$ osmium tetroxide, dehydrated in ethanol, critical point dried in a Balzers CPD-20 set. The samples were covered by $10 \mathrm{~nm}$-thick gold film in a Balzers MED-010 metalizer, observed and electromicrographed under a Phillips-SEM 515 microscope.

Spermatozoa dimensions were measured with the image analysis program Kontron Elektronik KS 300 v. 2.0. A mean value was determined for head length (HL) and head width (HW), midpiece length (ML) and flagellum length (FL) as well as total length (TL) in micrometers. Fifty-five spermatozoa from each semen sample were used for this purpose.

\section{Semen cryopreservation}

Sixteen males were used in this experiment and sperm motility (Fribourgh, 1966) was assessed at each collection. The ejaculates, in which motility was rated " 5 ", were later mixed for the preparation of a semen pool $\left(9.23 \pm 1.5 \times 10^{6} \mathrm{sperm} / \mathrm{mm}^{3}\right)$ with three replicates. The semen was diluted at a ratio of 1:3 (sperm:extender) at room temperature. The 
first aliquot was diluted in the type A extender, developed by Stein and Bayrle (1978), denominated "V2e", which was also utilized by Fogli da Silveira et al. (1981; 1984). It consisted of $\mathrm{NaCl} 750 \mathrm{mg}, \mathrm{NaHCO}_{3} 200 \mathrm{mg}, \mathrm{KCl} 38 \mathrm{mg}$, glucose $100 \mathrm{mg}$, distilled water $100 \mathrm{~mL}$, hen egg yolk $20 \mathrm{~mL}(\mathrm{pH}=8.0 ; 313 \mathrm{mOsm})$ and $10 \%$ dimethyl sulfoxide (DMSO). The second aliquot was diluted in type B extender which consisted of glucose $(5.0 \mathrm{~g})$, hen egg yolk $(10 \mathrm{~mL})$ and distilled water $(80 \mathrm{~mL})(\mathrm{pH}=6.38 ; 356 \mathrm{mOsm})$ and $10 \%$ DMSO, according to Hugo Pereira Godinho (oral communication).

The semen was filled into $0.5 \mathrm{~mL}$ straws or $4.0 \mathrm{~mL}$ straws (adapted bovine insemination sheaths (I.M.V., L'Aigle, France) sealed with cotton and polyvinylic alcohol at one end). Subsequently, the straws were laid on a steel screen tray and frozen in liquid nitrogen vapor, at $1 \mathrm{~cm}$ above the level of liquid nitrogen $\left(-185^{\circ} \mathrm{C}\right)$ inside an insulated Styrofoam ${ }^{\circledR}$ box. The freezing temperature was determined by a PT 100 thermocouple probe $\left(+100^{\circ} \mathrm{C}--200^{\circ} \mathrm{C}\right)$. Ten minutes later, the straws were plunged into liquid nitrogen and then transferred to a cryogenic container (CryometalDS- 34). Twenty-four hours after freezing, a fertilization assay was performed with eggs from six mature, three years-old females. Ovulation was induced with two injections of carp pituitary extract $(0.5 \mathrm{mg}$ and $5.0 \mathrm{mg} / \mathrm{kg}$ body weight, respectively) at 10 -hour interval. Six hours after the second injection, the eggs were obtained by gentle abdominal massage.

Thawed semen from a $0.5 \mathrm{~mL}$ straw was used to fertilize $4.0 \mathrm{~g}$ of eggs (approximately $4950 \mathrm{eggs}$ ) and a $4.0 \mathrm{~mL}$ straw was used to fertilize $20.0 \mathrm{~g}$ of eggs (approximately 24760 eggs). As a control, $0.2 \mathrm{~mL}$ of fresh semen provided by fresh semen pool, collected from six males, were used to fertilize $4.0 \mathrm{~g}$ of eggs and $0.5 \mathrm{~mL}$ for $20.0 \mathrm{~g}$ of eggs. Total sperm/egg ratio for all treatments is about $2,9 \pm 0.96 \times 10^{5}$ sperm/egg.

Thawing was carried out by immersing the $0.5 \mathrm{~mL}$ and $4.0 \mathrm{~mL}$ straws in a $36^{\circ} \mathrm{C}$ water bath for $10 \mathrm{~s}$ and 30 s, respectively. Subsequently, semen was spread over the eggs and gently mixed. Then, water was added in order to activate sperm. After twenty minutes, the eggs were washed with water and placed in an incubator and larvae started to hatch after 16 hours of incubation at $22^{\circ} \mathrm{C}$. The incubators were emptied, the larvae were collected and fixed in $4 \%$ formol solution and hatching rate was determined. These experiments were performed with three replicates.

In order to determine the degree of interaction between variables (straw size and diluent type) and hatching rate, the statistical software SAS (8.02) was used. Data were analyzed by ANOVA at a significance level of 5\% ( $\alpha=0.05)$, and data regarding significant effects were analyzed by the Turkey test $(\alpha=0.05)$.

\section{RESULTS}

Semen of Brycon cephalus was milky, almost transparent and showed low viscosity, high spermatic concentration $\left(X=9.617 \pm 1.6 \times 10^{6}\right.$ sperm $/ \mathrm{mm}^{3}$ ), and a relatively large volume after hormone induction (ranging from $4 \mathrm{~mL}$ of semen to over $10 \mathrm{~mL}$ ). Spermatozoa were of an average length (TL) of $31.288 \pm 4.47 \mu \mathrm{m}$ and was differentiated into a head, a midpiece and a tail or flagellum. The head was small, round shaped $(\mathrm{HL}=1.727 \pm 0,18 \mu \mathrm{m} ; \mathrm{HV}=1.752 \pm 0,17 \mu \mathrm{m})$, and almost totally occupied by a nucleus. The nucleus consisted of highly dense chromatin forming dense clots, covered by a cytoplasmatic membrane without acrosome (Figures $1 \mathrm{~B}$ and 1C). The nuclear fossa was deep and contained a proximal and a distal centriole (basal body), perpendicular to each other, and the initial portion of the flagellum (Figs. 1A, 1C, 1D). The midpiece (ML= $2.561 \pm 0.44 \mu \mathrm{m})$ started at the posterior region of the head, where the tail began, and narrowed toward the posterior end of the spermatozoa. In the cytoplasm of this region, mitochondria and several vesicles could be seen. Mitochondria were located in the anterior part of the midpiece and form a necklace around the initial portion of the flagellum (Figs. 1A, 1C, 1E). They were completely separated from the flagellum by the cytoplasmatic canal (Figure 1C, 1D).

The flagellum $(\mathrm{FL}=29.521 \pm 4.37 \mu \mathrm{m})$ of the spermatozoon arose from the basal body, located at the nuclear fossa (Figs. 1A, 1B, 1E). It was perpendicular to the base of the nucleus, though slightly eccentrical. It was formed by a basic axoneme with typical microtubules arrangement and consisted of nine peripheral doublets and a central pair (Fig. 2E). The ultrastructural examination (SEM; TEM) of thawed spermatozoa from all treatments, compared with that of fresh spermatozoa (Figs. 2C, 2F) revealed a range of 
that varied from swelling of the plasma membrane and midpiece retraction (Figs. 2A, 2B, 2D, 2G) to total destruction of the spermatozoon (Figs. 2E, $2 \mathrm{H})$. Some structural alterations were present in all thawed spermatozoa observed.

The results of fertilization tests demonstrated a significant effect $(\alpha=0.05)$ on the increasing of fertility in the diluted and frozen semen using the extender of $\mathbf{B}$ type, at both $0.5 \mathrm{~mL}$ and $4.0 \mathrm{~mL}$ straws. No significant effect $(\alpha=0,05)$ related to the utilization of $0.5 \mathrm{~mL}$ or $4.0 \mathrm{~mL}$ straws in relation to the hatching percentage, according to the adopted freezing method, was observed, despite of hatching differences favorable to the utilization of $0.5 \mathrm{~mL}$ straws (Fig. 3).

\section{DISCUSSION}

\section{Sperm characteristics}

Spermatozoa of several Brycon species (Romagoza, 1999; Aires, 1998; Zaiden, 2000) were very similar to each other and, therefore, similar to Brycon cephalus spermatozoa. Excepts by the chromatin density pattern, Brycon $s p$ spermatozoa could be classified as aquasperm type. According to Jamieson (1991), aquasperms usually have a head with a round-shaped nucleus containing homogeneous and highly dense chromatin, and a midpiece and cytoplasmatic canal of varying sizes.

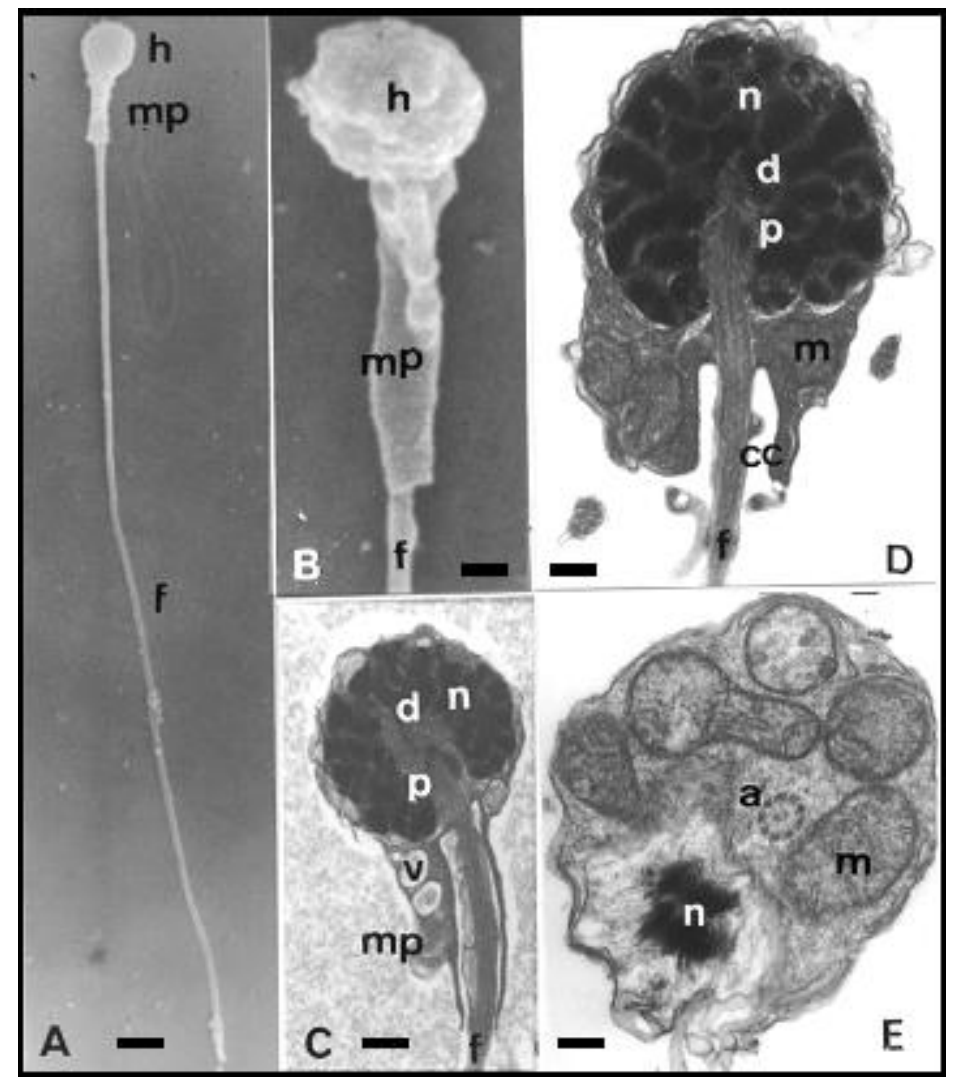

Figure 1 - Ultrastructural aspects of B. cephalus spermatozoa. Head (h), midpiece (mp), flagellum (f), nucleus (n), proximal centriole (p), basal body (d), mitochondria

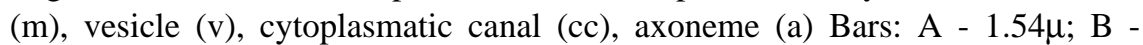
$0.38 \mu ; \mathrm{C}-0.63 \mu ; \mathrm{D}-0.29 \mu ; \mathrm{E}-0.37 \mu$

$\begin{aligned} & \text { Seminal volume and fertilization } \\ & \text { spermatozoalegg ratio }\end{aligned}$
The volume of semen produced by this species of the animal to obtain sperm as it
occured with the African catfish Clarias
after CPE induction make unnecessary the volume facilitated the application of


cryopreservation techniques and its high concentration allowed the use of different diluents, a better use of semen in the process of artificial fertilization and reduction of male broodstock. In studies with the African catfish, Clarias gariepinus, Rurangwa et al. (1998) demonstrated that both, excess of semen and low sperm concentration, reduced fertilization success. This was also observed by Levanduski and Cloud (1988) in the rainbow trout, Oncorhynchus mykiss. Scott and Baynes (1980) concluded that a small amount of good quality semen was enough to obtain a high fertilization rate.
The number of spermatozoa necessary to fertilize an egg among fishes is species specific. Furthermore, variations in the spermatozoa/egg ratio can occur according to egg or semen quality, among other factors (Table 1). On the other hand, regarding to thawed semen, the spermatozoa/egg ratio should be higher because, as demonstrated by Martinez and Ekwall (1998), the freezing/thawing may cause great mortality among spermatozoa besides damaging their cell structures (cell membrane, midpiece and flagellum) and thus disable them for fertilization (Fig. 2E, 2H).

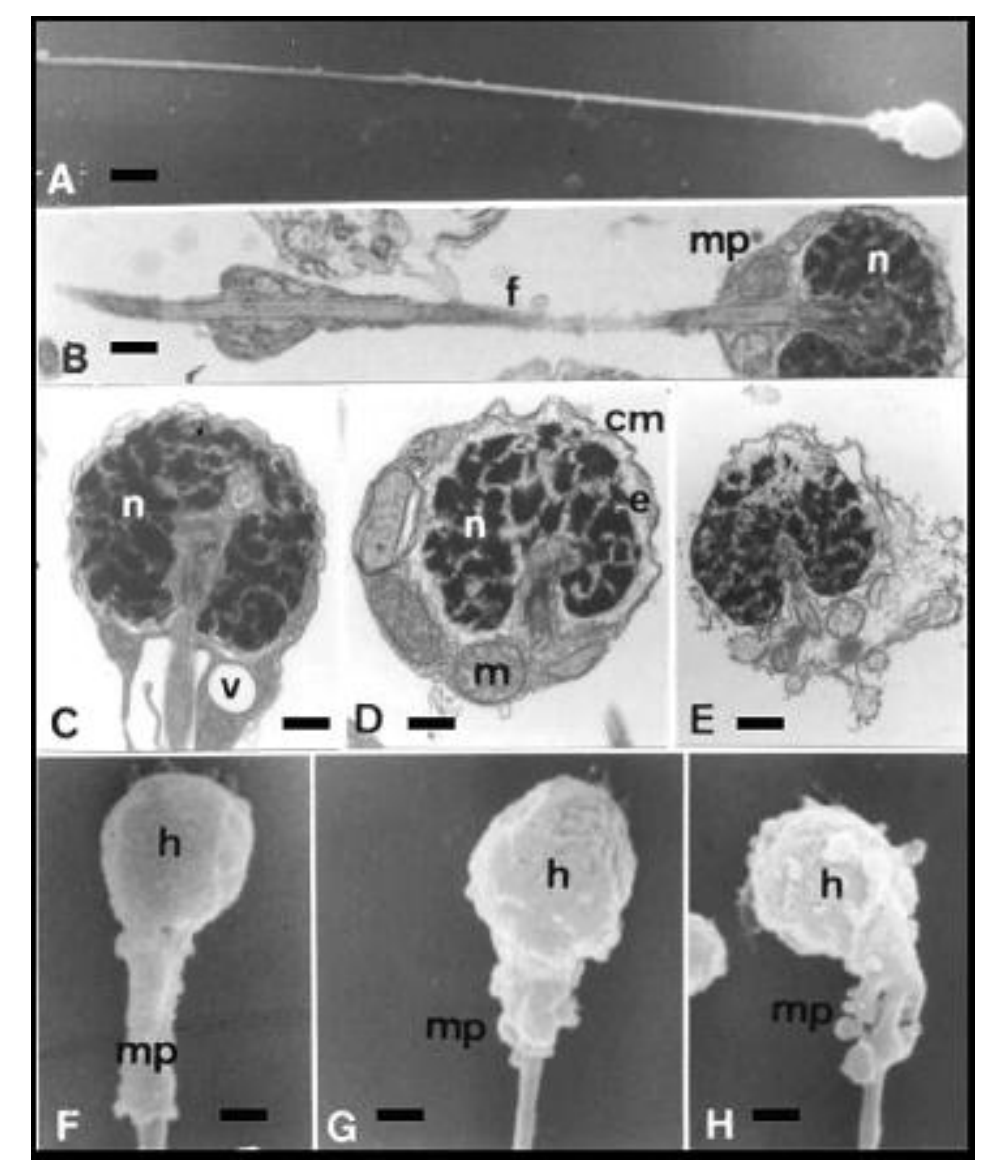

Figure 2 - Ultrastructural aspects of fresh $(\mathrm{C}$ and F) and thawed (A,B,D,E,G,H) B. cephalus spermatozoa (TEM and SEM): Head (h), midpiece (mp), flagellum (f), nucleus $(\mathrm{n})$, mitochondria $(\mathrm{m})$, vesicle $(\mathrm{v})$, swollen cytoplasm membrane $(\mathrm{cm})$, gap formed by freezing/thawing.

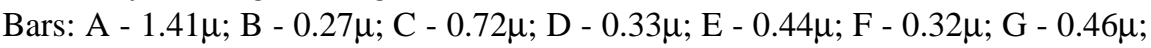
$\mathrm{H}-0.46 \mu$.

By analyzing the data shown in Figure 3, it might be inferred that the preservation of sperm characteristics was effective during semen freezing/thawing. In addition, the spermatozoa/egg ratio proved to be adequate for this species as relatively high hatching rates were observed. 


\section{Straw sizes, freezing, thawing and diluents}

Richardson et al. (1999), studying semen of Pleuronectes ferrugineus frozen in $0.25 \mathrm{~mL}$ and $1.7 \mathrm{~mL}$ straws, found that fertility rate in $1.7 \mathrm{~mL}$ straws was significantly lower. They considered that this fact was caused by a long freezing point plateau (the point of residual heat release at which ice crystals was formed by a rise in the temperature inside the straw) or a slower freezing rate caused by the straw of larger volume. In present experiments with $B$. cephalus, no significant difference $(\alpha=0.05)$ in hatching rate was observed between the straws size used. This could be attributed to the low freezing temperature used $\left(-185^{\circ} \mathrm{C}\right)$ and the fact that thawing occurred at $36^{\circ} \mathrm{C}$, thus providing homogeneous freezing and heating rates, exceeding or reducing the point of residual heat release, preventing the formation of ice crystals.

Different extenders can be used in the process of semen cryopreservation, ranging from those of a simpler composition to those compounded by several substances (Stein and Bayrle, 1978; Anderson and Mcneil, 1984; Lahnsteiner et al., 1996; Coser et al., 1987). Carosfeld et al. (2003) and Ribeiro and Godinho (2003) frozen the semen of characiforms species using extenders with simple composition, similar to the type B solution used in the present experiment, and they reached good fertilization results with the thawing semen.

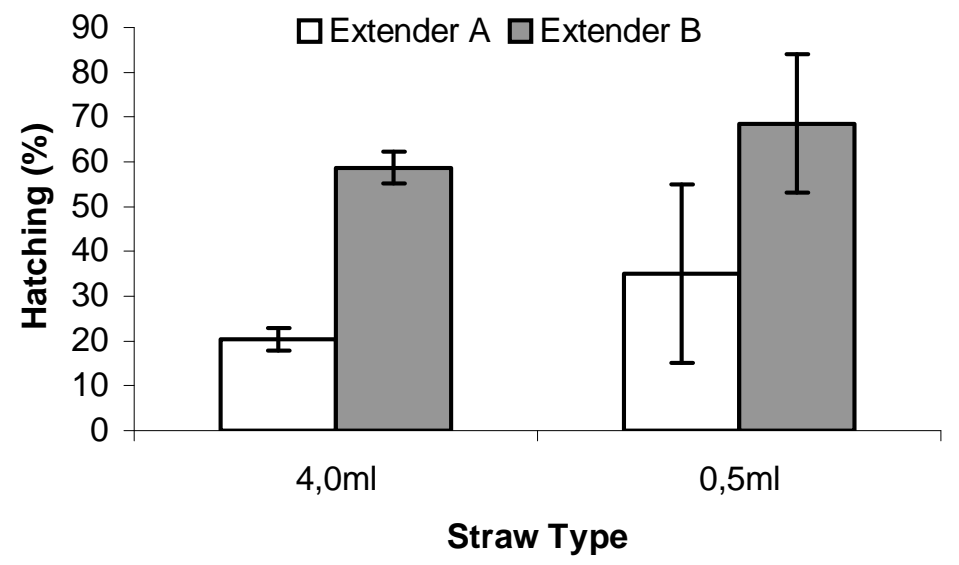

Figure 3 - Mean hatching rate, related to control test, obtained in all treatments used in the fertilization assay of frozen B. cephalus semen (Extenders: A and B; Straws: $0.5 \mathrm{~mL}$ and $4.0 \mathrm{~mL})(\mathrm{A} 0.5=35.06 \pm 2.48 \%, \mathrm{~A} 4.0=20.42 \pm 3.61 \%, \mathrm{~B} 0.5=$ $68.56 \pm 19.99 \%, \mathrm{~B} 4.0=58.73 \pm 15.39 \%)$

The diluents tested here, though simply compounded, showed a good protective action on the spermatozoa of this species. However, type B diluent had a more effective interaction in the maintenance of $B$. cephalus seminal characteristics with both straw sizes used $(0.5 \mathrm{~mL}$ and $4 \mathrm{~mL})$. These data agreed with previous observations with the semen of the rainbow trout, which suggested that a straw/extender/semen interaction occurred during freezing/thawing and that this interaction varied accordingly to the type of diluent (extender) and straw size used.

\section{Ultra-structural analysis of thawed spermatozoa}

The comparison between the ultrastructural data and the hatching rate obtained suggested that the structural alterations resultant from the freezing/thawing process, such as swelling of the membrane and retraction of the midpiece could not affect spermatozoa viability as high hatching rates were obtained and/or because the large quantity of spermatozoa/egg used allowed the minimization of the effects caused by defective spermatozoa on fertilization. 


\section{Cell activation}

In preliminary tests at $1 \% \mathrm{NaHCO}_{3}$ solution, Fogli da Silveira et al. (1990) successfully activated thawed semen of P. mesopotamicus. However, when this solution was used in this study during the fertilization process, the eggs clustered at the bottom of the container and hatching rate was zero. Apparently, the eggs were not hydrated. Thus, pond water was used as sperm activator as it provided a satisfactory motility and good fertilization results. The data here in presented demonstrated that the methods used for the cryopreservation of matrinxã semen were adequate for the production procedures as they were simple fast and provided good final results (production of larvae).

$\underline{\text { Table } 1 \text { - Optimal spermatozoa/eggs ratio in some teleosts updated (**) from Rurangwa (1998) }}$

\begin{tabular}{lcl}
\hline \multicolumn{1}{c}{ Fish species } & Sperm / egg & \multicolumn{1}{c}{ References } \\
\hline Asiatic Catfish (Clarias macrocephalu ) & $4-8,000$ & Tambassem-Cheong et al., 1995 \\
European Catfish (Silurus glanis L.) & 40,000 & Redondo et al., 1989 \\
Atlantic Croaker (Micropogonias & 1,000 & Gwo et al., 1991 \\
undulatus) & & \\
Carp ( Cyprinus carpio) & 13,000 & Marcel, 1981 \\
Pike (Esox lucius) & 26,000 & Erdhal and Graham, 1987 \\
Brown Trout (Salmo trutta) & 43,000 & Erdhal and Graham,1987 \\
Rainbow Trout (Oncorhynchus mykiss) & 20,000 & Billard and Carpentier, 1973 \\
Rainbow Trout (Oncorhynchus mykiss) & 300,000 & Billard, 1975 \\
Rainbow Trout (Oncorhynchus mykiss) ${ }^{* *}$ & 200,000 & Fogli da Silveira et al., 1988 \\
Turbot (Scophtalmus maximus) & 6,000 & Suquet et al. ,1995 \\
African Catfish (Clarias gariepinus) & 15,000 & Rurangwa et al., 1998 \\
\hline
\end{tabular}

\section{ACKNOWLEDGEMENTS}

This work was supported by Centro de Pesquisa e Gestão de Recursos Pesqueiros Continentais CEPTA/IBAMA, which provided the fish and the facilities used in this study, and also by CAPES and CNPq (Conselho Nacional de Pesquisa).

\section{RESUMO}

Visando o desenvolvimento das técnicas de reprodução em peixes, foi realizada a caracterização e a criopreservação do sêmen de Brycon cephalus. As características seminais observadas foram: sêmen de coloração leitosa quase transparente, com um volume médio de $4 \mathrm{~mL}$ e concentração espermática de $9.617 \pm 1.630$ x $10^{6}$ espermatozóides $/ \mathrm{mm}^{3}$. Os espermatozóides (comprimento $=31,288 \pm 4,47 \mu \mathrm{m})$ são do tipo "aquasperm", apresentando uma pequena cabeça arredondada (comprimento $=1,752 \pm 0,18 \mu \mathrm{m}$; largura $=1,752 \pm 0,17 \mu \mathrm{m}$ ) sem vesícula acrosomal, com um núcleo com cromatina altamente compactada, formando grumos grosseiros e um complexo centriolar localizado na fossa nuclear; uma peça intermediária (comprimento = $2,561 \pm 0,44 \mu \mathrm{m})$ que se estreita no sentido anteroposterior, um canal citoplasmático e um flagelo $($ comprimento $=29,521 \pm 4,37 \mu \mathrm{m})$. Os testes de fertilização com sêmen descongelado demonstraram um efeito significante $(\alpha=0,05)$ no aumento da fertilidade quando utilizado o diluente tipo B, para ambos os tipos de palhetas, $0,5 \mathrm{~mL}$ e $4,0 \mathrm{~mL}$. Não foi constatado efeito significativo $(\alpha$ $=0,05)$ entre a utilização de palhetas de $0,5 \mathrm{~mL}$ ou de $4,0 \mathrm{~mL}$ em relação à porcentagem de eclosão.

\section{REFERENCES}

Aires, E. D. (1998), Características morfológicas e histofisiológicas da via espermática da piracanjuba, Brycon orbignyanus (Pisces: Teleostei). Tese de Doutorado, Instituto de Biociências, Universidade Estadual Paulista, Botucatu, Brasil. pp. 69.

Anderson, R. and Macneil, A. J. (1984), Preliminary investigations of cryopreservation of milt of Atlantic salmon (Salmo salar) and it's application to commercial farming. Aquaculture, 43, 351-4. 
Billard, R. and Carpentier, H. (1973), Detérmination du nombre optimum de spermatozoides nécessaires à la fécondation d'un ovule au cours de l'insémination artificielle de la truite. Bull. Fr. Piscicult., 251, 73-6.

Billard, R. (1975), L'insémination artificielle de la truite (Salmo gairdineri, Richardson). V. Effets de la diluition et définition du rapport optimum gamétes / dilueur. Bull. Fr. Piscicult., 257, 121-135.

Carosfeld, J.; Harvey, B.; Fogli da Silveira, W.; Kavamoto, E. T.; Ramos, S. M. and Silveira, A N. (1990), Criopreservação do sêmen do pacu, Piaractus mesopotâmicus Holmberg, 1887. Bol. Tec. CEPTA, 3, 1-4.

Carosfeld, J.; Godinho, H.; Zaniboni, E. F. and Harvey, B. J. (2003), Cryopreservation of sperm in Brazilian migratory fish conservation. J. Fish Biol., 63, 472-89

Coser, A. M. L.; Godinho, H. and Ribeiro, D., (1984), Cryogenic preservation of spermatozoa from Prochilodus scrofa and Salminus Maxillosus. Aquaculture, 37, 387-90.

Coser, A. M. L. and Godinho, H. P. (1987), Torquato, V. C. Criopreservação de sêmen do Peixe Piau, Leporinus silvestrii (Boulonger, 1902). Arq. Bras. Med. Vet. Zootec., 39, 37-42.

Erdhal, A W. and Graham, E. F. (1987), Fertility of teleost semen as affected by diluition and storage in seminal plasma-mimicking medium. Aquaculture, 60, 311-21.

Fogli da Silveira, W.; Kavamoto, E. T. and Narahara, M. Y. (1981), Avaliação quali-quantitativa e criopreservação em forma de pellets do sêmen do bagre Rhamdia hilatii. In: Sociedade Brasileira para o Progresso da Ciência, 33., Salvador. Anais... Salvador, Brasil. pp. 620.

Fogli da Silveira, W.; Kavamoto, E. T. and Narahara, M. Y. (1985), Avaliação da qualidade e criopreservação em forma de pellets do sêmen do bagre, Rhamdia hilarii (Valencienes, 1840). B. Inst. Pesca, 12 : (4), 7-11.

Fogli da Silveira, W.; Kavamoto, E. T.; Rigolino, M. G.; Penteado, L. A. and Carvalho Filho, A. C. (1984), Primeiros resultados de fertilização com sêmen congelado de truta arco-iris, Salmo irideus Gibbons, no Brasil. B. Inst. Pesca, 11, 131-36.

Fogli da Silveira, W.; Kavamoto, E. T.; Rigolino, M. G. and Tabata, Y. A. (1988), Fertilidade do sêmen da truta arco-íris, Salmo irideus Gibbons, em diferentes concentrações de espermatozóides por óvulo. B. Inst. Pesca, 15 : (1), 51-54.

Fogli da Silveira, W.; Kavamoto, E. T.; Cestarolli, M. A.; Godinho, H. M.; Ramos, S. M. and Silveira, A. N. (1990), Avaliação espermática, preservação criogênica e fertilidade do sêmen do pacu, Piaractus mesopotâmicus (Holmberg, 1887), proveniente de reprodução induzida. B. Inst. Pesca, 17, 1-13.

Fribourgh, J. H. (1966), The application of a differential staining method to low-temperature studies on goldfish spermatozoa. Progr. Fish Cult., 28, 227-31.
Gwo, J. C.; Strawn, K.; Longnecker, M. T. and Arnold, C. R. (1991), Cryopreservation of Atlantic croaker spermatozoa. Aquaculture, 94, 355-75.

Ribeiro, R. I. M. A. and Godinho, H. P. (2003). Criopreservação do sêmen testicular do teleósteo piau-açu, Leporinus macrocephalus. Arq. Brás. Méd. Vet. Zootec., 55 : (1), 1-7.

Carosfeld, J.; Harvey, B.; Fogli da Silveira, W.; Kavamoto, E. T.; Ramos, S. M. and Silveira, A N. (1990), Criopreservação do sêmen do pacu, Piaractus mesopotâmicus Holmberg, 1887. Bol. Tec. CEPTA, 3, $1-4$.

Jamieson, B. G. M. (1991), Fish evolution and systematics: evidence from spermatozoa. Cambridge: University Press. pp. 319.

Lahnsteiner, F.; Patzner, R. A. and Weismann, T. (1996), Semen cryopreservation of salmonid fishes: Influence of handling parameters on the postthaw fertilization rate. Aquaculture, 27, 659-71.

Levanduski, M. J. and Cloud, J. G. (1988), Rainbow trout (Salmo gairdineri) semen: effect of non-motile sperm on fertility. Aquaculture, 75, 71-79.

Marcel, J. (1981), Contrôle de la reproduction et gestion des gamétes de quelques espéces de poissons téléostéens. Diplôme de 1'Ecole Pratique des Hautes Etudes, Lyon. pp. 132.

Martinez, H. R. and Ekwall, H. (1998), Electron microscopy in the assesment of cryopreserved spermatozoa viability. The Americas Microscopy and Analysis, May. pp. 11-13.

Mendonça, J. O. J. (1994), Criação de espécies do gênero Brycon no CEPTA / IBAMA. In: Annual Seminar on the Breeding of Brycon, Pirassununga. Proceedings... Pirassununga: CEPTA. pp. 31-48.

Pereira Filho, M. (1994), Estudos desenvolvidos no INPA (Manaus-Amazonas) com o matrinchã, Brycon cephalus (Günther, 1869). In: Annual Seminar on the Breeding of Brycon, Pirassununga. Proceedings... Pirassununga: CEPTA. pp. 25-30.

Redondo, C.; Hilge, V. and Billard, R. (1989), Artificial insemination of catfish (Silurus glani L.). Eur. Aquacult. Soc. Spec. Public., 10, 211-212.

Reynolds, E. S. (1963), The use of lead citrate at high $\mathrm{pH}$ as an electron opaque stain in electron microscopy. Cell Biol., 18, 8-13.

Richardson, G. F.; Wilson, C. E.; Crim, L. W. and Yao, Z. (1999), Cryopreservation of yellowtail flounder (Pleuronectes platessa) semen large straws. Aquaculture, 174, 89-94.

Romagosa, E.; Narahara, M. Y.; Borella, M. I.; Pariera, S. F. and Fenerich-Verani, N. (1999), Ultrastructure of the germ cells in the testis of matrinxã, Brycon cephalus (Teleostei, Characidae). Tissue and Cell, 31, 540-544. 
Rurangwa, E.; Roelants, I.; Huyskens, G.; Ebrahimi, M.; Kime, D. E. and Ollevier, F. (1998), The minimum effective spermatozoa:egg ratio for artificial insemination and effects of mercury on sperm motility and fertilization ability in Clarias gariepinus. J. Fish Biol., 53, 402-13.

Scott, A. P. and Baynes, S. M. (1980), A review of the biology, handling and storage of salmonid spermatozoa. J. Fish Biol., 17, 707-39.

Stein, H. and Bayrle, H., (1978), Cryopreservation of sperm of some fresh water teleosts. Ann. Biol. Anim. Biophys, 18, 1073-1076.

Suquet, M.; Billard, R.; Cosson, J.; Normant, Y. and Fauvel, C. (1995), Artificial insemination in turbot (Scophthalmus maximus): determination of the optimal sperm per eggg ratio and time of gamete contact. Aquaculture, 133, 83-90.

Tambasem-Cheong, M. V. P.; Tan-Fermin, J. D.; Garcia, L. M. B. and Baldevarona, R. B. (1995), Miltegg ratio in artificial fertilization of the Asian freshwater catfish (Clarias macrocephalus) injected salmon gonadotropin-realising hormone and domperidone. Aquat. Living Resour., 8, 303-307.

Viveiros, A. T. M.; So, N. and Komen, J. (2000), Sperm cryopreservation of African catfish, Clarias gariepinus: cryoprotectants, freezing rates and sperm:egg dilution ratio. Theriogenology, 54, 1395-1408.

Watson, M. L. (1958), Staining of tissue sections for electron microscopy witch heavy metals. J. Biophys. Biochem. Cytol., 4, 5-8.

Zaiden, S. F. (2000), Morfologia gonadal $e$ metabolismo energético da piraputanga Brycon hilarii (Cuvier e Valenciennes, 1849) (Pisces, Characidae), em cativeiro, durante o ciclo reprodutivo anual. Tese de Doutorado. Centro de Aqüicultura, Universidade Estadual Paulista, São Carlos, Brasil. pp. 152. 